\title{
Risk Scores in Heart Valve Surgery
}

Michel Pereira Cadore, João Carlos Vieira da Costa Guaragna, Luiz Carlos Bodanese

Hospital São Lucas da Pontifícia Universidade Católica do Rio Grande do Sul, Porto Alegre, RS - Brazil

\section{Dear Editor,}

We read with interest two manuscripts recently published in the Point-of-View session of this journal ${ }^{1,2}$, which discuss the importance of risk scores when indicating heart valve surgery.

The scores most frequently used to quantify the risk of death in patients undergoing heart valve surgery in our country were developed in populations with different characteristics from that of our country, thus determining limitation of its use, and this has already been demonstrated. The European System for Cardiac Operative Risk Evaluation (EuroSCORE) is probably the most widely known score. However, it is not specific for heart valve surgery, because in the development of this score data from heart valve surgeries and from coronary artery bypass grafting were associated.

We express our perplexity because our study published in this journal, and conducted in our Institution, has not been considered. We presented a score developed from a database of 1086 patients which exclusively underwent heart valve surgery ${ }^{3}$. Discrimination of the model developed according to the ROC curve (Receiver Operating Characteristics) was 0.83 (95\% Cl 0.78-0.86). Score calibration calculated by the Hosmer-Lemeshow $(\mathrm{H}-\mathrm{L})$ test indicated a good performance of the model $\left(r=0.98, x^{2}=5.61\right.$ and $\left.p=0.691\right)$. Our score had internal validation, obtaining a ROC curve of 0.84 and a $\mathrm{H}$-L test with $\mathrm{p}=0.37$, and also were validated in another national institution ${ }^{4}$, obtaining a 0.78 ROC curve and a $\mathrm{H}$-L test with $p=0.81$. In our study, the overall death rate was $11.8 \%$, and, in elective surgeries, $8.8 \%$. Our score is unique, because it is the only one in our country capable to estimate the risk of death in patients undergoing isolated heart valve surgery. Currently, this score, along with another one developed in our institution for patients undergoing coronary artery bypass grafting $^{5}$, is routinely used in our daily practice and applied along with EuroSCORE. In the near future, recalibration of the scores and comparative studies with the EuroSCORE will be possible to be done.

\section{Keywords}

Heart valve surgery; risk scores.

Mailing Address: Michel Pereira Cadore •

Sape, 50 / 304, Passo DAreia. Postal Code 91350-050, Porto Alegre, RS - Brazil E-mail: michelcadore@cardiol.br, michel_cadore@hotmail.com Manuscript received September 21, 2012, revised manuscript October 01 2012; accepted December 05, 2012.

\section{References}

1. Casalino R, Tarassoutchi F. Escores de risco nas intervenções em valvopatia. Arq Bras Cardiol. 2012;98(5):e84-6.

2. Casalino R, Grinberg M. A inclusão do escore de risco na tomada de decisão em cardiopatia valvar. Arq Bras Cardiol. 2012;98(6):e102-4.

3. Guaragna JC, Bodanese LC, Bueno FL, Goldani MA. Proposta de escore de risco pré-operatório para pacientes candidatos à cirurgia cardíaca valvar. Arq Bras Cardiol. 2010;94(4):541-8
4. Sá MP, Sá MV, de Albuquerque AC, da Silva BB, de Siqueira JW, de Brito $\mathrm{PR}$, et al. Guaragna SCORE prediz satisfatoriamente os desfechos em cirurgia cardíaca valvar em hospital brasileiro. Rev Bras Cir Cardiovasc. $2012 ; 27(1): 1-6$.

5. Cadore MP, Guaragna JC, Anacker JF, Albuquerque LC, Bodanese LC, Piccoli JC, et al. Proposição de um escore de risco cirúrgico para pacientes submetidos à cirurgia de revascularização miocárdica. Rev Bras Cir Cardiovasc. 2010;25(4):447-56. 